\title{
Leitura em infográfico web: multimodalidade em sala de aula
}

\author{
Lectura en infografía web: multimodalidad en el aula
}

\section{Reading in web infographic: multimodality in classroom}

\author{
Bruna Carolini Barbosa* \\ Monique Susan Morara Lavisio** \\ Wéllem Aparecida de Freitas Semczuk***
}

\begin{abstract}
RESUMO: Os avanços trazidos pela tecnologia têm ocasionado o emergir de novos gêneros pautados em novos suportes. Sendo o infográfico web um novo gênero emergido dessa ascensão multimodal, procuramos propor aos docentes uma nova ferramenta para o ensino de leitura. Ao considerar a circulação de infográficos web em exames nacionais e vestibulares, acreditamos que eles não têm sido frequentemente explorados em sala de aula. Por isso, pretendemos apresentar uma proposta de ensino com gênero infográfico web voltado ao alunado do Ensino Médio. Pautados em aportes teóricos como Bronckart (2006); Shepherd e Watters (1999); Marcuschi (2005), Pinheiro (2010), Dionísio (2011), Kato (1995), Solé (1998), Paiva (1998), entre outros, buscamos ampliar a capacidade leitora do aluno, letrando-o no gênero em questão, e preparando-o para atuar em diferentes esferas, assim como nos exames nacionais. Como medida, buscamos com esta proposta de ensino dar suporte ao trabalho docente.
\end{abstract}

PALAVRAS-CHAVE: Gênero Infográfico Web. Leitura. Multiletramentos.

RESUMEN: Los avances traídos por la tecnología han ocasionado el surgir de nuevos géneros pautados en nuevos soportes. Siendo el infográfico web un nuevo género emergido de esa ascensión multimodal, procuramos proponer a los docentes una nueva herramienta para la enseñanza de lectura. Al considerar la circulación de infografías web en exámenes nacionales y vestibulares, creemos que a menudo no se han explorado en el aula. Por eso, pretendemos presentar una propuesta de enseñanza con género infográfico web orientado al alumnado de la Enseñanza Media.

*Mestra em Estudos da Linguagem e doutoranda pelo Programa de Pós-Graduação em Estudos da Linguagem da Universidade Estadual de Londrina - PPGEL/UEL. Professora colaboradora no curso de Letras da Universidade Estadual do Norte do Paraná - UENP. brunabarbosa@uenp.edu.br

**Mestra em Estudos da Linguagem pelo Programa de Pós-Graduação em Estudos da Linguagem da Universidade Estadual de Londrina - PPGEL/UEL. Professora de inglês nas séries iniciais no município de Londrina. mnk susan@hotmail.com

***Mestra em Estudos da Linguagem e doutoranda pelo Programa de Pós-Graduação em Estudos da Linguagem da Universidade Estadual de Londrina - PPGEL/UEL. Professora na Universidade Pitágoras Unopar - modalidade a distância. wellemsemczuk@gmail.com 
Pautas en aportes teóricos como Bronckart (2006); Shepherd y Watters (1999); (1998), Pío (1998), Pío (1998), Darioísio (2011), Kato (1995), Solé (1998), Paiva (1998), entre otros, buscamos ampliar la capacidad lectora del alumno, letándolo en el género en cuestión, y preparándolo para actuar en diferentes esferas, así como en los exámenes nacionales. Como medida, buscamos con esta propuesta de enseñanza dar soporte al trabajo docente

PALABRAS CLAVE: Género Infográfico Web. Lectura. Multiletramentos.

ABSTRACT: The advances brought by technology have led to the emergence of new genres based on new media. As the web infographic is a new genre emerged from this multimodal rise, we try to propose to teachers a new tool for teaching reading. When considering the circulation of web infographics in national and vestibular exams, we believe that they have not been frequently explored in the classroom. Therefore, we intend to present a teaching proposal with a web infographic genre aimed at secondary school students. Guided by theoretical contributions such as Bronckart (2006); Shepherd and Watters (1999); Marcuschi (2005), Pinheiro (2010), Dionísio (2011), Kato (1995), Solé (1998), Paiva (1998), among others, sought to broaden the learner's reading ability, writing it in the genre in question, and preparing it to work in different fields, as well as national examinations. As a measure, we seek with this teaching proposal to support the teaching work.

KEYWORDS: Infographic genre Web. Reading. Multiletramentos.

\section{Introdução}

Este artigo tem o intuito de apresentar uma proposta de ensino do gênero multimodal infográfico web, direcionada a estudantes de Ensino Médio. $\mathrm{Na}$ tentativa de contribuirmos para um ensino mais produtivo, buscamos explorar a leitura no infográfico Web Operação Lava Jato, do jornal Folha S. Paulo online. Tendo em vista que este gênero é muito utilizado em exames nacionais e vestibulares, proporemos a ideia de diagnosticar modos de leitura para verificar o nível de letramento imagético dos alunos, preparando-os para atuar nesses determinados exames. Sabemos que o Exame Nacional do Ensino Médio, doravante ENEM, avalia o desempenho do estudante em relação as suas capacidades de escrita e leitura ao final desse ciclo.

Desse modo, retrataremos uma metodologia na perspectiva de trabalhar a habilidade leitora do aluno, letrando-o para o gênero. Primeiramente, exporemos um aporte teórico voltado aos estudos de gênero e suas multimodalidades, formas de leitura e, logo após, apreciaremos o infográfico 
web como instrumento de ensino formador de sujeitos críticos, baseando em análises do contexto de produção, em seus aspectos discursivos e seu caráter verbo-visual. Por fim, apresentaremos uma proposta de ensino voltada a estes aspectos de leitura.

Em face a essa realidade, buscamos empoderar o aluno por meio da linguagem para atuar nas inúmeras esferas comunicativas advindas das evoluções tecnológicas, inserindo o sujeito em práticas comunicativas efetivas, agindo por meio da linguagem.

\section{Gêneros Discursivos Digitais}

A comunicação é inerente ao ser humano que, para se comunicar, faz uso da linguagem em suas diversas modalidades. Assim, os textos construídos em meio a sociedade são produtos da atividade de linguagem, estando em funcionamento permanente nas formações sociais decorrentes, muitas vezes, em função de seus objetivos, interesses e questões específicas. A elaboração destas formações acaba por produzir diferentes tipos de textos, que apresentam características relativamente estáveis, disponíveis no intertexto como modelos indexados (BRONCKART, 2006).

Os gêneros discursivos são compreendidos por Marcuschi (2005) enquanto entidades dinâmicas, formas culturais e cognitivas de ação social, corporificadas na linguagem. Assim incluem toda sorte de diálogos cotidianos bem como enunciações da vida pública, institucional, artística, científica e filosófica.

Diante do exposto, entendemos que o gênero não pode ser pensado fora da sua dimensão espácio-temporal. Logo, todas as formas de representação que nele estão abrigadas são, igualmente, orientadas pelo espaço-tempo, ou seja, o contexto de produção do texto é essencial para sua compreensão. Para Schneuwly (1994b apud BRONCKART, 2003, p.103), "os gêneros são meios sócio-historicamente construídos para realizar os objetivos de uma ação de 
linguagem; em termos marxistas, são, portanto, instrumentos, ou megainstrumentos mediadores dos seres humanos no mundo".

Ao falar de dinamicidade, compreendemos que os gêneros são dinâmicos e variáveis estão em constante processo de mudança, renovam-se e multiplicam-se. Esse processo de adoção-adaptação dos gêneros gera novos exemplares, mais ou menos diferentes dos exemplares preexistentes, e que, consequentemente, é pelo acúmulo desses processos individuais que os gêneros se modificam permanentemente e tomam um estatuto fundamentalmente dinâmico ou histórico. Essa proliferação de novas variedades de gêneros merece atenção e, de acordo com Marcuschi (2005), estão sempre surgindo a partir de outros gêneros, ou seja, como desmembramento desses devido às necessidades e às inovações tecnológicas.

Bakhtin e Volochínov (1995) afirmam que

as relações sociais evoluem, depois a comunicação e a interação
verbais evoluem no quadro das relações sociais, as formas dos atos
de fala evoluem em consequência da interação verbal, e o processo
de evolução reflete-se, enfim, na mudança das formas da língua
(BAKHTIN; VOLOCHÍNOV, 1995, p. 124).

Com o advento da internet, surgiram então os chamados gêneros digitais (SHEPHERD e WATTERS, 1999; MARCUSCHI, 2005; PINHEIRO, 2010).

Para Shepherd e Watters (1999), diante das mudanças institucionais e da combinação entre computador e internet, os gêneros passaram por diversas alterações, fazendo com que alguns fossem reconfigurados e outros novos emergiram por causa do novo suporte.

Marcuschi (2005) classifica esses gêneros enquanto relativamente variados, porque a maioria apresenta similares em outros ambientes, tanto na modalidade oral quanto escrita.

Para Pinheiro (2010), sua origem pode ser vista como resultado das novas exigências da interação verbal nos contextos digitais. E sua existência não é isenta de influências, porque, como enfatiza o autor, um gênero é um componente de um conjunto, estabelecido social, histórico e culturalmente. 
Desta maneira, os gêneros digitais, emergentes das tecnologias, têm trazido e provocado inúmeras discussões, principalmente no âmbito educacional, pois houve um impacto na linguagem e, consequentemente, na vida social, o que por muitos é visto como algo negativo. Criticam os ambientes virtuais por serem versáteis e possibilitarem variadas formas de linguagem, 0 que se não forem bem trabalhadas em sala de aula, realmente, podem trazer malefícios à aprendizagem dos alunos, principalmente, no que diz respeito à norma padrão, um dos objetivos propostos pela escola no ensino de línguas.

Pensando em gêneros como social, cultural e historicamente construídos, essa "revolução" na comunicação, com o surgimento dos gêneros online, é um fenômeno que pode ser visto como natural, mesmo que suas consequências sejam inimagináveis.

Como características dos gêneros digitais, Pinheiro (2010) acentua a interatividade simultânea, a velocidade de trânsito das informações, a interação do internauta com o texto e do internauta com outro internauta, as inúmeras possibilidades de textos e a influência de outras formas de comunicação.

Shepherd e Watters (1999), por outro lado, referem-se aos gêneros digitais como cybergêneros, os quais são caracterizados pelo conteúdo, forma e funcionalidade. Para os autores, a funcionalidade é a grande marca do cybergênero, uma vez que os interlocutores criam expectativas a respeito da interação com esse gênero e o que esperar dele.

Em vista disto, os gêneros aparecem como objetos de ensino capazes de desenvolver leitura, escrita e fala dos alunos, focando e vivenciando a língua em uso, por meio de práticas situadas para a cidadania. Portanto, a apropriação dos gêneros é um mecanismo fundamental de socialização, de inserção prática nas atividades comunicativas humanas. 


\section{Gêneros Multimodais e Multiletramentos}

A internet tem possibilitado a comunicação entre pessoas de forma versátil e pluralista. Com o seu surgimento, pôde-se notar a emergência de muitos gêneros e esses gêneros causam polêmicas quanto a sua natureza e proporção, impacto na linguagem e vida social. Todavia eles têm ocupado cada vez mais seu espaço nas interações comunicativas, muito provavelmente pelo fato de reunir em um só meio variadas formas de expressão, múltiplas semioses, rapidez e flexibilidade linguística.

Mediante a emergência da tecnologia na sociedade contemporânea, a necessidade em se repensar a noção de letramento torna-se indispensável. $\mathrm{Na}$ sociedade mediada pelas novas tecnologias, a relação entre imagem e palavra é facilmente percebida, visto que a sociedade está cada vez mais visual. Disso decorre a importância de se refletir a respeito do letramento verbal e não verbal, ou seja, sobre os letramentos multimodais, já que a apreensão do sentido em sua totalidade só se dá através da leitura que integra as diferentes linguagens de um texto.

Os gêneros textuais são materializações das ações culturais e se a comunicação social utiliza várias linguagens, então, os gêneros também serão multimodais. Os gêneros estão diretamente ligados às ações sociais em suas várias esferas e situações dentro delas. Os usuários, incluídos nessa infinidade de situações comunicativas, fazem uso dos gêneros, mesclando as várias linguagens disponíveis que se fizerem necessárias à construção do sentido.

Dionísio (2011) chama a atenção para o fato de que não considera multimodais apenas os textos com imagens e desenhos, por exemplo, mas a própria disposição gráfica do texto é constituinte do seu aspecto visual, como no caso dos poemas concretos. Uma reflexão possível é que essa percepção da autora está diretamente ligada a um dos elementos constitutivos do gênero elencados por Bakhtin: a forma composicional.

Se partimos da premissa de que todo texto escrito ou falado é multimodal, então teremos que levar em consideração que existem textos 
multimodais mais padronizados e outros mais flexíveis, além de ser importante compreender que há existência de um contínuo informativo visual dos gêneros textuais escritos que vai do menos visivelmente informativo ao mais visivelmente informativo (DIONÍSIO, 2011). A estrutura do texto e sua organização em uma página, virtual ou física, já diz muito sobre seu gênero.

É irrefutável a importância de se trabalhar textos multimodais em sala de aula, já que esses gêneros estão presentes na sociedade, e somente sendo capaz de dominar essas linguagens é que o indivíduo estará exercendo integralmente sua cidadania. $\mathrm{O}$ trabalho pedagógico pautado na perspectiva de multiletramentos pressupõe que se leve em consideração as experiências do aluno enquanto sujeito historicamente constituído, para partir de sua vivência para novas experiências e significações. Dessa forma,

\begin{abstract}
trabalhar com multiletramentos pode ou não envolver (normalmente envolverá) o uso de novas tecnologias da comunicação e de informação ('novos letramentos'), mas caracteriza-se como um trabalho que parte das culturas de referência do alunado (popular, local, de massa) e de gêneros, mídias e linguagens por eles conhecidos, para buscar um enfoque crítico, pluralista, ético e democrático - que envolva agência - de textos/discursos que ampliem o repertório cultural, na direção de outros letramentos [...] (ROJO; MOURA, 2012, p.8).
\end{abstract}

Os multiletramentos apontam para um multiculturalismo e multiplicidade de linguagem, embora as instituições de ensino ainda privilegiem a cultura "culta". A escola tem por responsabilidade propiciar experiências significativas aos alunos, em que eles possam defender seus pontos de vista e opiniões, serem protagonistas em seus aprendizados e, para isso, é preciso reconhecer a importância dos gêneros digitais, já que vários deles têm sido oficializados pelo discurso dominante e adotado pelo Estado. Portanto, para que o sujeito consiga intervir socialmente precisará dominar os gêneros dessa determinada esfera.

Além de empoderar o aluno por meio da linguagem para agir em diferentes situações comunicativas advindas das evoluções tecnológicas, é preciso considerar planos de ensino que tomem por base o sujeito inserido em um tempo e espaço e que age por meio da linguagem, consequentemente, 
pensaremos em estratégias de ensino que serão mais significativas a eles e que permitirão que compreendam a si e ao mundo.

Além dos textos que estão em suportes como revistas, computadores, televisão etc., com os quais os alunos estão frequentemente em contato, sabemos que há uma crescente utilização de textos multimodais em exames nacionais e decorre daí a necessidade de se analisar como se dá a construção do sentido nesses gêneros, e em que medida a imagem se relaciona com o sentido global do texto.

Oliveira (2013) aponta para a relevância da Gramática do Design Visual, uma vez que esta teoria é utilizada para valorizar o desenvolvimento de práticas que promovam a multiplicidade de linguagens e reafirma essa valorização, argumentando sobre a possibilidade de se ler um texto não verbal como qualquer outro texto, bem como o caráter social dos textos multimodais, que emprega a linguagem visual socialmente construída, como qualquer modo semiótico. Ignorar esses aspectos faz com que a escola gere iletrados visuais e "o empoderamento semiótico depende da compreensão das diferentes semioses presentes em cada gênero" (OLIVEIRA, 2013, p.3).

Os documentos oficiais também apontam para a necessidade de se estimar os letramentos múltiplos e isso já está claro até mesmo no título da área de Língua Portuguesa. Esse documento orienta um ensino pautado nos gêneros discursivos, para um desenvolvimento crítico do aluno, pois é preciso que ele domine os muitos gêneros que circulam nas diversas esferas sociais, 0 que justifica a necessidade de se desenvolver os letramentos múltiplos.

\section{Gênero Infográfico}

O infográfico é um texto que tem sido muito utilizado pela mídia jornalística em diversas publicações, seja impressa ou online. Dionísio (2006, p. 138) o conceitua como sendo uma "criação gráfica que utiliza recursos visuais (desenhos, fotografias, tabelas etc.), conjugados a textos curtos para apresentar informações jornalísticas de forma sucinta e atraente". 
Uma das principais características do infográfico baseia-se na veracidade, pois seu uso tem por intuito não levar o leitor ao erro interpretativo, mas sim auxiliá-lo na compreensão do texto. Em vista disso, há dois propósitos para o uso do infográfico: (i) caráter jornalístico (ii) caráter didático. Aquele é utilizado para complementar a informação veiculada em uma notícia, ou seja, geralmente explica um fato trazido no texto, com o intuito de facilitar a compreensão. Já este pode aparecer sem o acompanhamento de uma reportagem ou notícia. Por causa destes usos, Dionísio (2006) não considera o infográfico como um gênero textual, mas sim um recurso que acompanha 0 gênero notícia.

Através desta conceituação e de seu uso já recorrente em nossa sociedade, acreditamos que sua utilização enquanto recurso didático em sala de aula poderá ampliar e incentivar a leitura dos alunos, principalmente, quanto ao infográfico presente no meio digital. Por isso, escolhemos analisar, neste trabalho, os infográficos presentes no jornal Folha de S. Paulo Online, na seção Folha Explica, em que temos o assunto político sobre a Operação Lava Jato.

Pretendemos, após a leitura do texto, analisar os infográficos, com base em Paiva (2011), demonstrando seus aspectos contextuais, discursivos e verbovisuais, para em um segundo momento propormos um plano de ensino do gênero infográfico para as turmas do Ensino Médio.

Nesta reportagem, há 10 seções em que o leitor pode escolher por qual começar, clicando sobre os títulos de seu interesse, e em cada título há um infográfico que ajuda a explicá-lo. Assim, disponibilizamos, a seguir, a reportagem conforme aparece no jornal online e logo depois os infográficos que estão presentes em cada título. 
Figura 1: Infográfico Operação Lava Jato

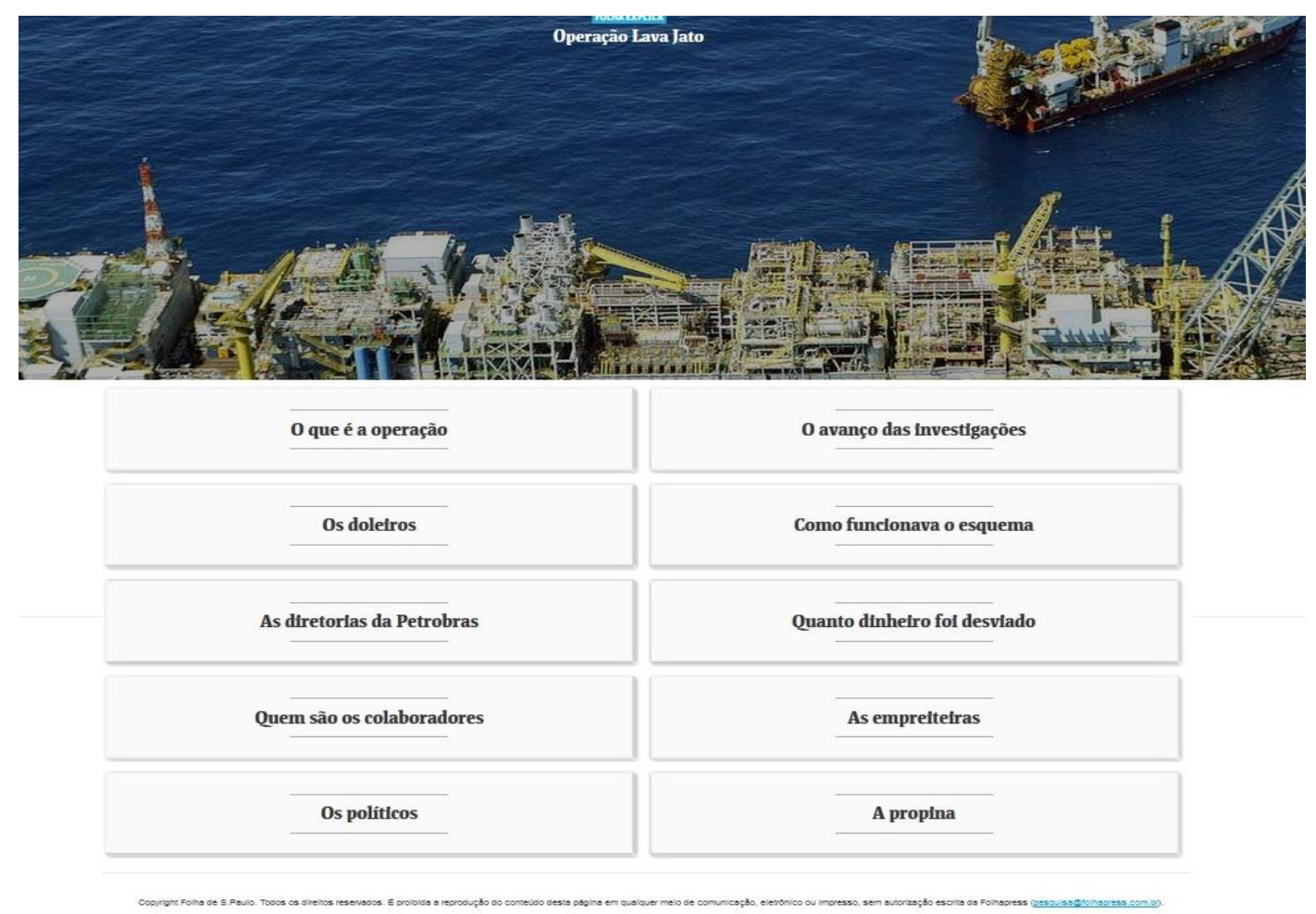

Disponível em: <http://arte.folha.uol.com.br/poder/operacao-lava-jato/>. 
Figura 2: Infográfico 1

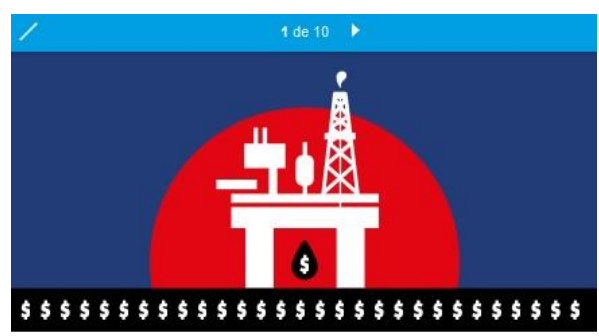

0 que é a operação

A Operação Lava Jato é a maior investigaçăo sobre corrupção conduzida até hoje n Brasil. Ela começou investigando uma rede de doleiros que atuavam em vários Estados e descobriu a existencia de um vasto esquema de corrupçâa na
envolvendo polticos de vários partidos e as maiores empretteras do pais

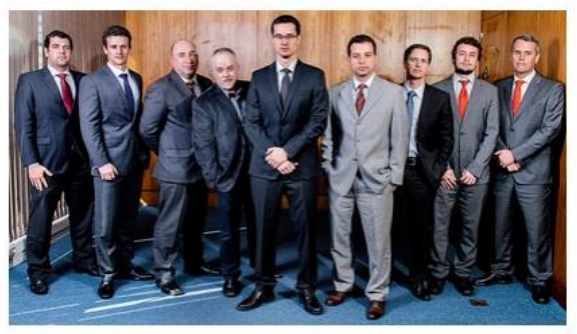

๑

Figura 4: Infográfico 3

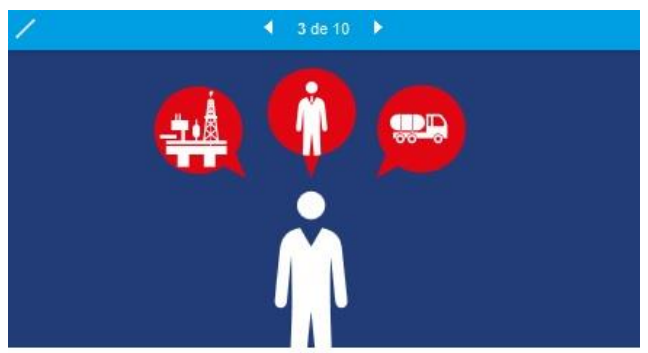

Os doleiros

Apontado como um dos principais operadores do esquema, o doleiro Alberto Youssef é um velho conhecido das autoridades. Ele foi investigado e processado antes por seu envolvimento com um esquema de lavagem de dinheiro que movimentou bilhôes de dólares a partir de contas do antigo Banestado, no Paraná. O doleiro Carlos Habib Chater, seu parceiro em Brasilia, usava um posto de combustiveis como fachada para seus negócios, e foi dai que surgiu o nome da Operaçãa Lava Jato

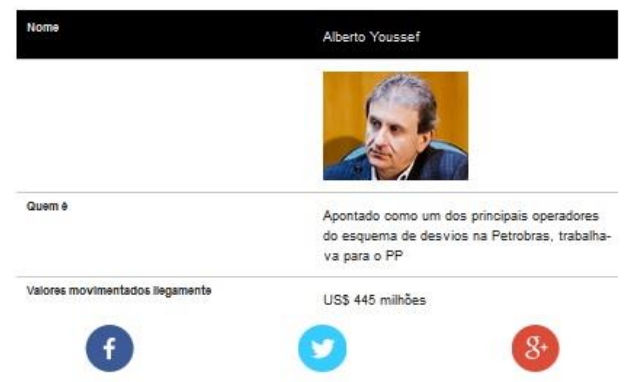

Figura 3: Infográfico 2

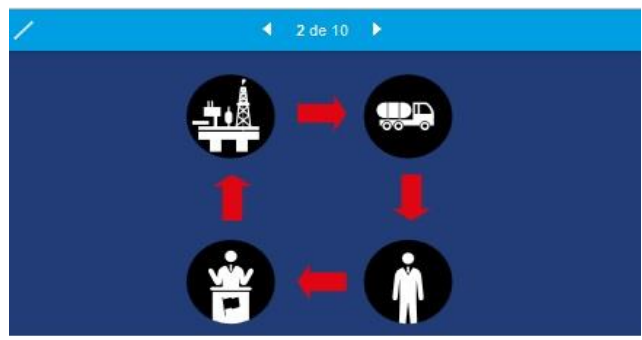

O avanço das investigações

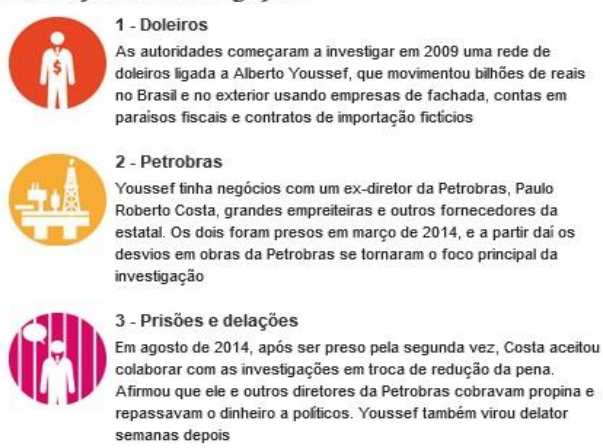

(f)

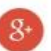

Figura 5: Infográfico 4

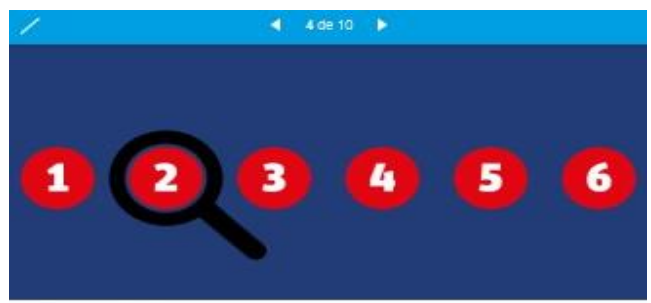

Como funcionava o esquema

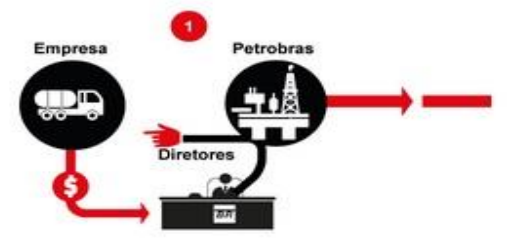

1 - PROPINAS

Segundo o Ministerlo PUDllios Federal. olretores e tuncionarlos da Petrooras cobravam propha de enpreneiras e outros tornecsobres para taclitar seus negocilos com a estatal

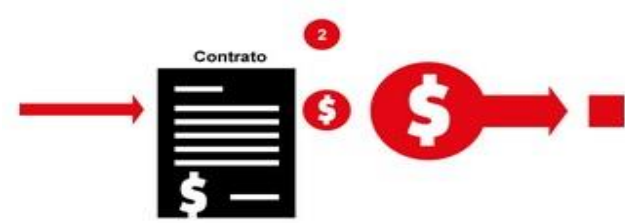


Figura 6: Infográfico 5

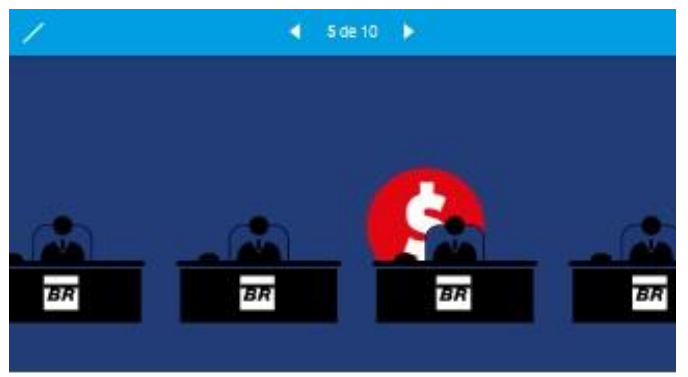

As diretorias da Petrobras

As inestigaphes se concentram soore tres diretorlas da Petrobras e as pessoss que passaram a controlar essas areass apos a chegada do PT ao poder, en 2003 . Segunoo Paul Foberto Costa e Albero Yousset, casta diretor era responstivel por recoiner propha das empresas com oontratos na sua area e repassa-la ao partico que he garantla 0 apols poitlioo necessarlo para conthuar no cargo. Cada area thns um operasor para tazer a dilstrioulģ̧o do dinnelro, segunso os delatores

\begin{tabular}{|c|c|}
\hline Marm & Poulo Roberso Costa \\
\hline untans & ADssiscimento \\
\hline 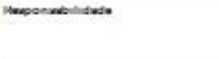 & $\begin{array}{l}\text { Retingriss, peroquimica e assriloulçbio no } \\
\text { Erasill }\end{array}$ \\
\hline Modo & $2004: 2012$ \\
\hline retdo polltos & PP E PMIOS \\
\hline Uperester sennoget & Aloeno Yousset \\
\hline 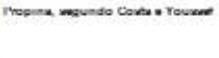 & 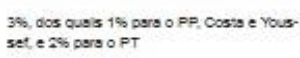 \\
\hline
\end{tabular}

Figura 8: Infográfico 7

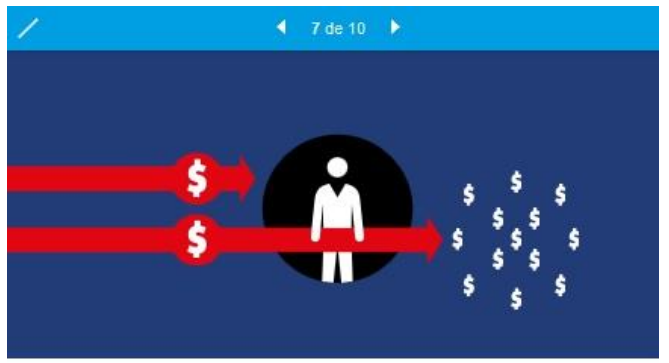

Quem são os colaboradores

Previstos na legislação brasileira, os acordos de delação premiada deram grande impulso às investigaçôes. Os delatores se comprometem a contar tudo o que sabem sobre os crimes de que participaram e a fornecer provas, alem de devolver recursos obtidos liegalmente. Em troca, receben garantias de que suas penas serão reduzida ao final dos processos na Justiça. Alguns advogados acham que o juiz Sergio Moro que conduz os processos da Lava Jato no Parana, manteve suspeitos presos por muito tempo sem justificativa razoâvel, para força-los a colaborar. Mas vários delatores aceitaram cooperar quando estavam em liberdade. A tabela mostra quem são os principais colaboradores da Operaçãa Lava Jato

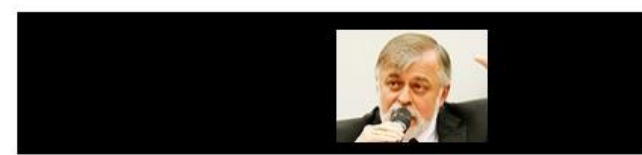

Paulo Roberto Costa

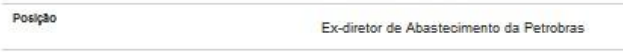

f
Figura 7: Infográfico 6

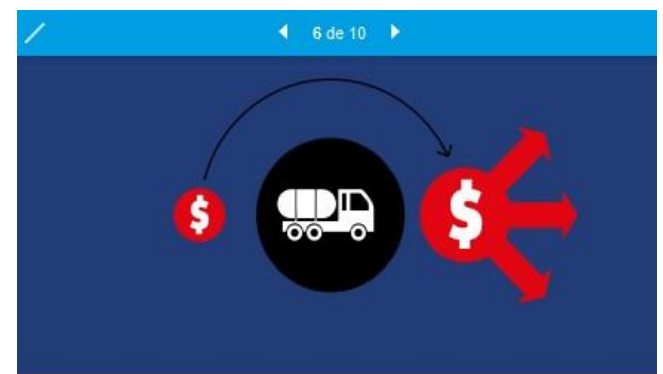

Quanto dinheiro foi desviado

Nos processos em andamento na Justiça, o Ministério Público Federal estima que RS 2,1 bilhões foram desviados dos cofres da Petrobras, mas é possivel que o valor do prejuizo seja muito maior. No balanço de 2014, publicado com atraso em maio deste ano, a Petrobras estimou em RS 6,1 bilhöes as perdas provocadas pela corrupçäo. Para fazer essa estimativa, a estatal examinou todos os contratos com as empresas sob investigação e aplicou sobre o seu valor o porcentual de $3 \%$ indicado por Paulo Roberto Costa como a propina cobrada em sua área

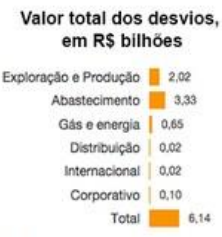

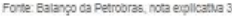$$
\text { Total } \quad \text { 6.14 }
$$

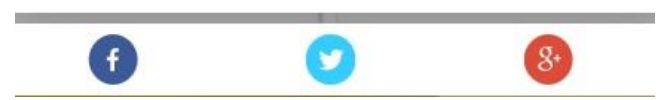

Figura 9: Infográfico 8

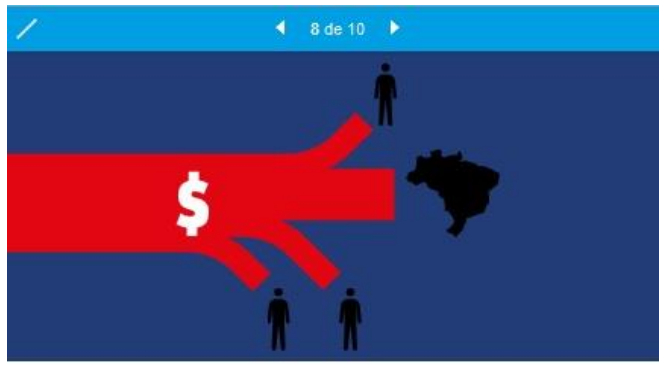

\section{As empreiteiras}

As maiores empreiteiras do país têm negócios com a Petrobras e se tornaram alvo das investigaçôes. Vários executivos, incluindo os controladores de algumas dessas empresas, foram presos em novembro de $2014 \mathrm{e}$ ficaram na cadela ate o final de abril, quando o Supremo Tribunal Federal mandou soltá-los. Em 19 de junho deste ano, as prisões atingiram a Odebrecht e a Andrade Gutierrez. Cinco empreiteiras são alvo de ações civis na Justiça, em que o Ministério Público cobra RS 4,5 bilhôes em indenizaç̃̃es. As empresas sob investigação estão impedidas de obter novos contratos da Petrobras, e várias enfrentam dificuldades financeiras porque perderam acesso a crédito após a Operação Lava Ja

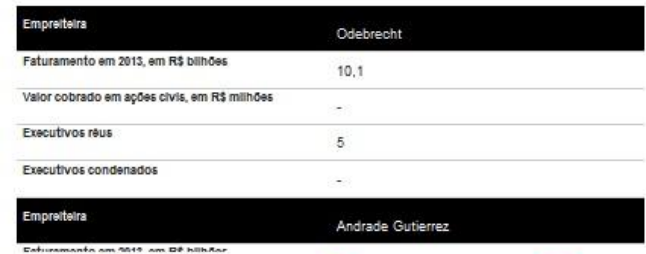


Figura 10: Infográfico 9

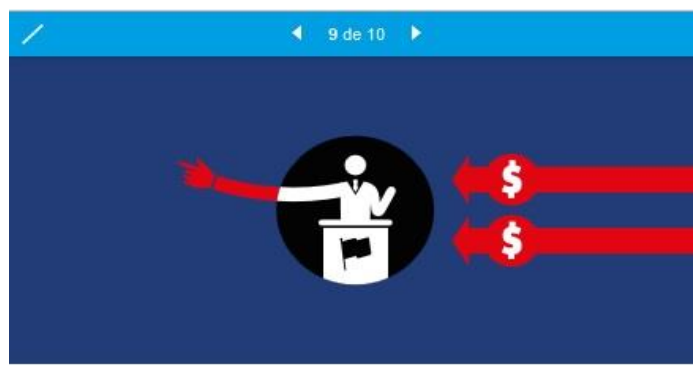

\section{Os políticos}

As investigações sobre os politicos começaram em março, quando a

Procuradoria-Geral da República conseguiu autorização do STF (Supremo Tribunal Federal) e do STJ (Superior Tribunal de Justiça) para investigar 53 pessoas, incluind deputados federais, senadores e dois governadores, de seis partidos politicos. Todos negam envolvimento com o esquema. A Procuradoria decidiu que não havi elementos para abrir inquérito sobre a presidente Dilma Rousseff, embora um dos delatores afirme que o esquema de corrupção ajudou a financiar sua campanha eleitoral em 2010

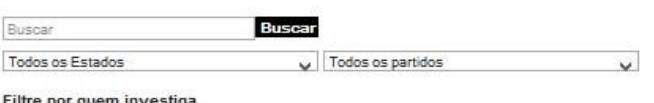

Filtre por quem investiga

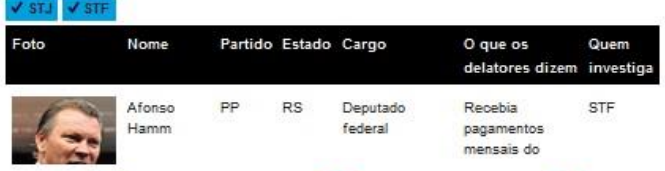

$f$
Figura 11: Infográfico 10

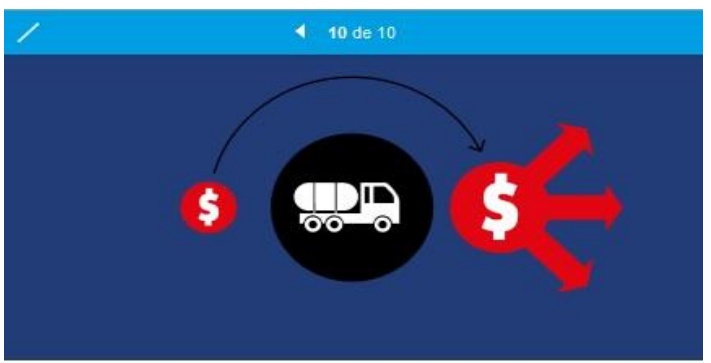

\section{A propina}

Como parte de seu acordo de colaboração premiada, o ex-gerente da Petrobras Pedro Barusco entregou ao Ministério Público Federal uma planihha em que registrou detalhes sobre o pagamento de propina em 89 contratos da Petrobras. De acordo com as anotações de Barusco, cerca de RS 1,2 bilhão em propina foi repassado a
poĺticos e funcionários da Petrobras como ele, o equivalente a $1 \%$ do valor total dos contratos

QUEM PAGOU. *

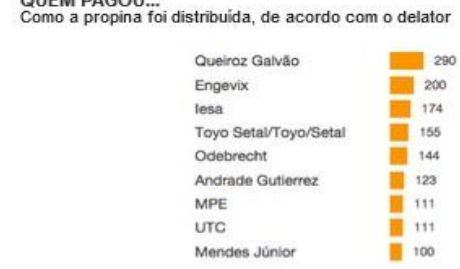

DIIFM FNTRFFIII

\section{Leitura em Infográficos Web}

Nesta seção, apresentaremos algumas considerações teóricometodológicas sobre leitura, com o intuito de compreender o processo de leitura do infográfico. Iniciaremos abordando as noções de leitura para, em seguida, apresentar critérios da leitura voltados ao infográfico.

Partimos do ponto de que a leitura é um meio de interação do indivíduo com o ambiente em que vive. Por meio dela, o sujeito compreende a realidade que o cerca e chega a conclusões sobre o seu mundo e os aspectos que o permeiam.

Em busca de uma abordagem da leitura em sua complexidade, recorreremos ao pensamento de Coscarelli (1999): 
A leitura é como um processo complexo que envolve desde a percepção dos sinais gráficos e sua tradução em som ou imagem mental até a transformação dessa percepção em idéias, provocando a geração de inferências, de reflexões, de analogias, de questionamentos, de generalizações, etc. (COSCARELLI, 1999, p.33).

$\mathrm{Na}$ realidade, desenvolver esta compreensão exige valer-se das habilidades de leitura para 0 entendimento das inúmeras áreas do conhecimento e o conhecimento do mundo.

Diante disso, podemos dizer que a habilidade de leitura se compõe de inúmeras estratégias para a compreensão de dado texto. Essas estratégias auxiliam o alunado a aplicar seu conhecimento prévio e a desempenhar inferências para a sua interpretação, identificando e esclarecendo o que não entende.

De acordo com Kato (1995),

\begin{abstract}
A leitura pode ser entendida como um conjunto de habilidades que envolve estratégias de vários tipos. Essas habilidades seriam: a de encontrar parcelas significativas do texto; a de estabelecer relações de sentido e de referência entre certas parcelas do texto; a de estabelecer coerência entre as proposições do texto; a de avaliar a verossimilhança e a consistência das informações extraídas; a de inferir o significado e o efeito pretendido pelo autor do texto (KATO, 1995, p. 107).
\end{abstract}

Nesse sentido, as estratégias de leitura dizem respeito às maneiras que o leitor se utiliza para auxiliar o entendimento dos elementos informativos de um texto. Com isso, os critérios de assimilação de conhecimento adotados se diferenciam, variando de pessoa a pessoa, pois nós, individualmente, não absorvemos conhecimento da mesma forma.

Diante dos diferentes modos de assimilação, alguns indivíduos encontram dificuldades de ler - principalmente no que tange aos infográficos, pois estes foram criados para facilitar a compreensão de assuntos complexos, mas por vezes ainda causam certo estranhamento perante algumas inferências.

Para Kato (1995),quando se enfrenta uma tarefa mais difícil na leitura, o leitor tende a regredir no uso de estratégias, isto é, tende a imprimir a 
interpretação mais canônica ao estímulo, através de uma ativação bottom-up ${ }^{1}$ de seus esquemas.

Devemos, pois, antes de tudo, reconhecer que o indivíduo-leitor se utiliza de estratégias de compreensão leitora inconscientemente e que ao se deparar com dificuldades na leitura, ele se apropria de diversas estratégias para o entendimento superficial ou total do texto. Geralmente, o indivíduo recorre a estratégias como: a interrupção da leitura, inferências, busca de palavras desconhecidas, antecipações, dentre outras. Uma vez detectada essa complicação, é vital o ponderamento no ensino de estratégias de compreensão leitora. Acreditamos que seja necessário o indivíduo compreender o que são essas estratégias e qual o seu papel na leitura. A este propósito, levam-se em consideração alguns fatores de atividades cognitivas no ensino de estratégias de leitura, dentre eles, podemos citar, segundo Solé (1998):

Compreender os propósitos implícitos e explícitos da leitura; ativar e aportar à leitura conhecimentos prévios relevantes para o conteúdo em questão; dirigir a atenção ao fundamental; avaliar a consistência interna do conteúdo expressado e sua compatibilidade com o conhecimento prévio e com o "sentido comum"; comprovar continuamente se a compreensão ocorre mediante a revisão e a recapitulação periódica e a auto-interrogação; elaborar e provar inferências de diverso tipo, como interpretação, hipóteses e previsões e conclusões (SOLÉ, 1998, p. 73).

Como se vê, essas atividades cognitivas são necessárias para formar leitores autônomos e cidadãos críticos na leitura, capazes de enfrentar textos complexos e de estabelecer relações entre o que se lê e o que faz parte de seu acervo pessoal, questionando seu conhecimento e o ampliando-o ao mesmo tempo.

Para organizar estas atividades cognitivas, é preciso que 0 indivíduo se apodere de alguns domínios para o processo de leitura. De acordo com Paiva (2009),

\footnotetext{
${ }^{1}$ Leitura ascendente - processamento de informações - constrói o significado por meio da análise e síntese do significado das partes.
} 
1. o processamento lexical: reconhecimento do leitor das palavras do texto, bem como seus morfemas.

2. o processamento sintático: reconhecimento do leitor das ligações sintáticas possíveis entre as palavras de uma sentença.

3. a construção da coerência (ou significado) local: reconhecimento do leitor das proposições possíveis para uma sentença formada por palavras.

4. a construção da coerência temática: reconhecimento do leitor das relações entre sentenças; formação de inferências.

5. construção da coerência externa ou processamento integrativo: reconhecimento do leitor da produção de informações feita por ele durante a leitura, comparando-a com as informações que já dispõe para efetuar juízos de valor acerca do que leu: foi-lhe útil, mudou sua forma de pensar sobre o assunto, alterou sua memória a respeito daquele assunto? (PAIVA, 2009 apud COSCARELLI, 1999, p. 51).

Mediante os domínios citados, compreendemos que o esclarecimento de cada um deles ao indivíduo é indispensável para a utilização das estratégias, pois se houver falha em algum domínio, a leitura poderá se comprometer. Por isso, é necessário que utilizemos estratégias de leitura que, conforme foram apresentadas por Solé (1998), corroboram com a proposta de esquema de leitura de infográficos criada por Paiva (2009). Dentre estas estratégias estão:

1. Processamento de partes das imagens: responsável pelo reconhecimento de partes das imagens: elementos primários como brilhos, cores, linhas limítrofes, etc.

2. Processamento das relações entre partes da imagem: construção das relações entre as partes da imagem, estrutura das imagens, como os elementos primários, processados anteriormente se relacionam aqui.

3. Construção do sentido local: construção do sentido entre as partes de uma imagem, qual o sentido da relação entre as partes: por exemplo: a relação entre brilho e cor forma uma explosão?

4. Construção do sentido global: construção do sentido entre as imagens do infográfico. Como as imagens se relacionam umas com as outras?

Cada etapa necessita de atenção especial, pois o infográfico é composto por linguagem verbal e visual. A escrita e a imagem se complementam para o significado do todo, e a organização do gênero permite que o leitor aprecie o 
texto, construindo seus sentidos de forma fragmentada até chegar ao sentido global do texto.

Em suma, pautados em Solé (1998) e Paiva (2009), entendemos que o ensino das estratégias de leitura devem oferecer a seus aprendizes os procedimentos que permitem que o leitor adquira objetivos para leitura e atualização dos conhecimentos prévios relevantes; que o permitam estabelecer inferências de diferentes textos, além de rever e comprovar a própria leitura em tomada de decisões adequadas ante erros e falha na compreensão; e o processo que permite a recapitulação do conteúdo, resumindo-o e ampliando-o mediante o que absorve da leitura.

Tais observações nos levam a notar que o ensino de estratégias de leitura traz inúmeras atribuições na leitura em circunstâncias que articulem a aprendizagem significativa do indivíduo.

\section{Análise}

A escolha desta reportagem ocorreu por se tratar de um assunto atual e estar presente em todos os meios de comunicação, sendo mais fácil para 0 aluno ter acesso aos acontecimentos. Dessa forma, vamos fazer a análise dos infográficos nos baseando na pesquisa realizada por Paiva (2011), porém adaptamos sua metodologia, pois vamos considerar somente os aspectos contextuais, discursivos e verbo-visuais, conforme demonstra a tabela 1.

Tabela 1: Metodologia de pesquisa para o trabalho com o infográfico

\begin{tabular}{|c|c|c|c|c|}
\hline Análise & 0 que é & $\begin{array}{c}\text { Componentes } \\
\text { analisados }\end{array}$ & $\begin{array}{c}\text { Método de } \\
\text { análise/objetivo }\end{array}$ & Hipóteses \\
\hline Contextual & $\begin{array}{c}\text { A função } \\
\text { pragmática do } \\
\text { contexto, } \\
\text { texto como } \\
\text { ato de fala. }\end{array}$ & $\begin{array}{c}\text { Recursos } \\
\text { extratextuais: } \\
\text { suporte, } \\
\text { intencionalidade } \\
\text { do autor, } \\
\text { aceitação do } \\
\text { locutor. }\end{array}$ & $\begin{array}{l}\text { Descrever } \\
\text { componentes, com } \\
\text { propósito de } \\
\text { categorizar. }\end{array}$ & $\begin{array}{c}\text { Infográficos } \\
\text { possuem } \\
\text { contextos } \\
\text { específicos } \\
\text { na esfera } \\
\text { jornalística e } \\
\text { divulgação } \\
\text { científica. }\end{array}$ \\
\hline
\end{tabular}




\begin{tabular}{|c|c|c|c|c|}
\hline Discursiva & $\begin{array}{c}\text { A função } \\
\text { comunicativa. }\end{array}$ & $\begin{array}{c}\text { Conteúdo } \\
\text { temático, } \\
\text { estratégias } \\
\text { retóricas. }\end{array}$ & $\begin{array}{c}\text { Categorizar as } \\
\text { informações } \\
\text { normalmente } \\
\text { veiculadas pelos } \\
\text { infográficos. }\end{array}$ & $\begin{array}{c}\text { Infográficos } \\
\text { possuem a } \\
\text { função } \\
\text { específica de } \\
\text { informar } \\
\text { como foi, } \\
\text { como é e/ou } \\
\text { como } \\
\text { funciona } \\
\text { algo. }\end{array}$ \\
\hline $\begin{array}{c}\text { Verbo- } \\
\text { visual }\end{array}$ & $\begin{array}{c}\text { A } \\
\text { materialidade } \\
\text { do gênero } \\
\text { textual. }\end{array}$ & $\begin{array}{c}\text { Texto escrito e } \\
\text { visual. }\end{array}$ & $\begin{array}{c}\text { Analisar a relação } \\
\text { entre informação } \\
\text { visual e linguística. }\end{array}$ & $\begin{array}{c}\text { O infográfico } \\
\text { integra } \\
\text { informação } \\
\text { visual e } \\
\text { linguística. }\end{array}$ \\
\hline
\end{tabular}

Fonte: Adaptado de Paiva (2011).

ANÁLISE CONTEXTUAL

Os infográficos que aparecem na reportagem discutem o tema da Operação Lava Jato, no Jornal Folha de S. Paulo Online, embora apareçam de maneira fragmentada, acompanham o texto da reportagem, ou seja, há uma interdependência entre eles. Por isso, é considerado infográfico jornalístico, já que existe em razão de outros textos, sendo utilizado como um recurso a mais na reportagem, o que auxilia na compressão textual. É importante frisarmos essa conceituação para diferenciá-lo do infográfico de divulgação científica, pois este não depende de um texto-base, sua significação está presente nele mesmo.

Os infográficos escolhidos circulam na esfera jornalística, assim, possuem um contexto de produção específico com fins determinados, muitas vezes, pelo autor e/ou posicionamento do jornal. Desta maneira, são empregados a fim de descrever os componentes do gênero, neste caso, o jornal apresenta infográficos para cada título a ser discutido, com o intuito de aclarar cada detalhe da reportagem, misturando linguagem verbal e não verbal, para transmitir uma informação visual, mostrando a notícia com detalhes, utilizandose de diferentes recursos como imagens, gráficos, tabelas e mapas, com o objetivo de atingir um público maior e que este consiga fazer a leitura 
adequada do texto.

A escolha deste suporte ocorreu por se tratar de um veículo de grande circulação, um dos mais lidos do país, precursor na versão online, que desde 2010 está disponível em forma de aplicativo; além disto, apresenta em seu "menu" a página que direciona aos infográficos, ou seja, há um lugar específico em que o leitor pode ter acesso há textos que se utilizam deste gênero.

\section{ANÁLISE DISCURSIVA}

O infográfico web em questão une, por meio da relação informação e informática, duas categorias em busca de atribuir sentidos à constituição de um discurso jornalístico. Nesta perspectiva multimodal, há uma relação do modo discursivo com o modo semiótico. Ao ilustrar de modo informativo o fenômeno Operação Lava Jato, tão discutido entre as mídias, a Folha Online de S. Paulo utiliza o gênero infográfico para mobilizar uma concepção de língua instrumental para sustentar a ação efetiva comunicativa do infográfico.

Podemos dizer que a estrutura desse discurso se baseou em o que pode ser dito, de que modo e como. Para Kress e Van Leeuwen (2010), o discurso é o conhecimeto construído socialmente sobre (algum) aspecto da realidade, que está relacionado ao seu modo de realização, se realizando em variados modos. Dessa forma, os discursos marcadamente visuais podem ser realizados por diversos caminhos.

Diante dos fatos, ao analisar a sequência discursiva dos 10 infográficos que compõem a notícia da Operação Lava Jato, constatamos que o seu modo de formulação é determinante para a construção do sentido. A narrativa dos fatos se revela de forma didatizada, expondo-se organizadamente com textos compreensíveis e detalhados; com linguagem clara e concisa de cada tópico, facilitando a leitura e a compreensão do leitor sob todos os temas constituintes desse grande esquema de lavagem de dinheiro. O discurso é composto por um vocabulário sem rebuscamento, focado na relação de linguagem verbal e não verbal; somados a recursos gráfico-visuais com um design esclarecedor de 
ícones, como setas e cores. Os infográficos se constituem de elementos claros e objetivos articulando palavras e imagens para melhor informar a matéria jornalística.

ANÁLISE VERBO-VISUAL

Através do discurso, podemos agir sobre o outro, direcionando seu ponto de vista, para tanto, utilizamos os recursos verbo-visuais. A disposição das imagens no infográfico analisado permite reconhecer que, no processo de construção de sentidos, as imagens possuem uma intencionalidade subjacente, procurando conduzir a leitura e a adesão do que está sendo comunicado, a aceitação de valores ideológicos. Os ideogramas simulam uma ausência de sentidos, mas reafirmam o que está sendo dito verbalmente, de forma esquemática, como na imagem que segue, utilizada quando o infográfico fala sobre os delatores.

Os ideogramas são utilizados para fazer referência a seres, por exemplo, pessoas e animais. Geralmente, quando empregados para representar uma pessoa, a imagem é composta apenas pela silhueta, ou seja, sombra do corpo, entretanto, na imagem 1, essa representação é feita de modo a referenciar especificamente os supostos envolvidos na operação, uma vez que estes estão trajados com roupas sociais, usualmente adotadas por políticos, o que leva o leitor a pressupor que não se trata de pessoas comuns, mas de algum cargo importante. Um outro elemento bastante utilizado é o cifrão para enfatizar os altos valores envolvidos no que, verbalmente, chamam de "Grande Esquema de Corrupção". 
Figura 12: Exemplo de corrupção

Figura 13: Formato em $\mathrm{V}$
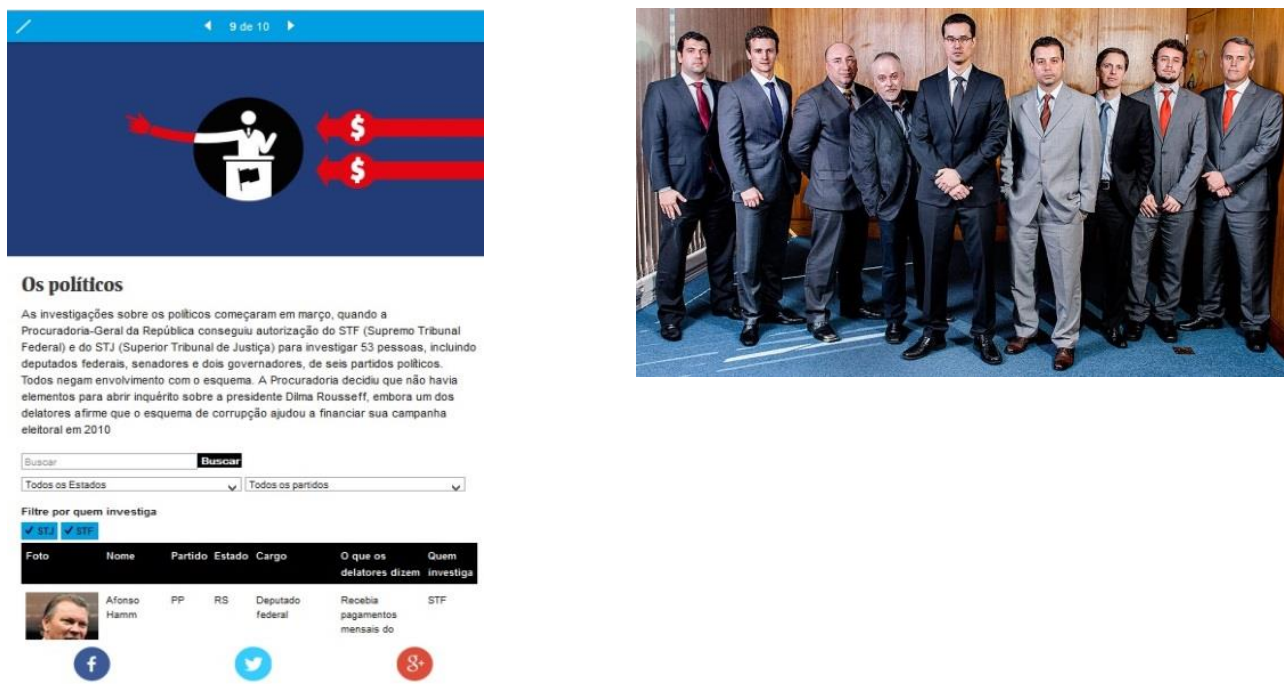

A figura 12 é utilizada quando o texto verbal se refere ao envolvimento dos políticos investigados. No texto, há o trecho "A Procuradoria decidiu que não havia elementos para abrir inquérito sobre a presidente Dilma Rousseff, embora um dos delatores afirme que o esquema de corrupção ajudou a financiar sua campanha eleitoral em 2010". O discurso construído vale-se da conjunção concessiva "embora" para sugerir uma dúvida ao que foi mencionado anteriormente, e essa dúvida é sugerida também na imagem, quando o político, no palanque, apresenta uma mão em tamanho maior, para fora do círculo preto, na cor vermelha do partido, muito utilizada em todo o infográfico. A mão em tamanho maior representa a estratégia saliência, utilizada "para dar maior ou menor destaque a certos elementos no texto visual" (NASCIMENTO, et. al. 2011, p.545).

Além dos ideogramas, são utilizadas as fotos dos investigados e dos procuradores responsáveis por conduzir a investigação, e podemos inferir algumas significações a partir da análise das categorias da Gramática Visual.

$\mathrm{Na}$ "função de interação", as imagens constroem relações entre os participantes e o leitor. Essas relações utilizam recursos visuais que podem ser: pelo contato do olhar; pela representação do participante distante ou próximo do leitor (distância social); pelo ângulo entre o corpo do participante e leitor no 
eixo vertical, denotando atitude, e entre participante e leitor no eixo horizontal, denotando poder. Essa identificação se dá com base no plano da câmera: "plano fechado - close-up (íntimo), plano médio - medium shot (social) e plano aberto - long shot (impessoal) (NASCIMENTO, 2011).

O contato é um recurso utilizado para expressar a pessoalidade (contato visual direto) ou impessoalidade (não há contato visual direto) da relação entre participante e leitor. A relação entre participante e leitor pode variar em níveis de maior intimidade, vínculo social, ou maior impessoalidade (NASCIMENTO, 2011). No infográfico, as fotos dos investigados e das pessoas envolvidas apontam predominantemente para a impessoalidade, já que apenas em 14 das fotos, de um total de 72 , há um contato visual direto, denotando uma maior impessoalidade e um menor vínculo de intimidade social.

A atitude está relacionada ao posicionamento do corpo do participante em relação ao leitor, e esse posicionamento pode significar maior ou menor envolvimento. Através do ângulo que o participante é captado, ao girar o eixo vertical obtemos três posições: frente, lado ou costas. 0 ângulo frontal denota maior envolvimento; o distanciamento acontece nos ângulos oblíquos, ou seja, de lado (NASCIMENTO, 2011). Das 72 fotos dos investigados, 54 apresentam posicionamento lateral, portanto, reafirmando a impessoalidade e distanciamento.

A foto dos procuradores responsáveis pelas investigações permite inferências altamente significativas. Podemos notar que a impessoalidade e distanciamento aqui são refutados, já que a foto aponta um contato visual direto e predominante posicionamento frontal dos procuradores. Temos a imagem no nível do olhar, sugerindo igualdade de poder.

Um outro fator a ser mencionado é a disposição em "V" utilizada nessa composição. Essa disposição não é neutra de sentido, pois, com base em uma inferência intertextual, podemos relacioná-la à formação de voo das aves, que voam nessa formação devido ao seu espírito cooperativo (para diminuir a turbulência e poupar energia) por um objetivo comum. A formação em "V" é 
também utilizada pelos super-heróis da "Liga da Justiça", responsáveis por combater as maldades e injustiças.

Uma disposição na foto que parece neutra é, na verdade, cheia de significações e valores ideológicos, já que com isso o objetivo pretendido é caracterizar os procuradores como super-heróis responsáveis por combater as injustiças em um espírito cooperativo de pôr um fim "a maior investigação sobre corrupção conduzida até hoje no Brasil" (trecho retirado do infográfico).

Há uma variada gama de novos gêneros oriundos das tecnologias e a imagem ocupa um papel importante dentro desse contexto. Podemos inferir disso que "as imagens assim como a linguagem verbal, devem ser entendidas enquanto sistema semiótico[...] que utilizamos para representar nossas experiências e negociar nossa relação com os outros" (NASCIMENTO et al., 2011). Há um aspecto bastante pertinente no que tange ao ensino da habilidade de lidar com os textos multimodais, já que há um equivocado pensamento por parte das pessoas de que essa habilidade se dá de forma implícita, ou seja, que é uma linguagem universal, portanto, automática, uma vez que esses textos socialmente construídos e ideológicos precisam de uma mediação pedagógica. 


\section{Proposta de Ensino Para Turmas do Ensino Médio}

\begin{tabular}{|c|c|c|c|c|c|c|c|}
\hline & Oficina 1 & Oficina 2 & Oficina 3 & Oficina 4 & Oficina 5 & Oficina 6 & Oficina 7 \\
\hline Conteúdo & $\begin{array}{c}\text { Apresentação da } \\
\text { Proposta de Ensino } \\
\text { e do Gênero } \\
\text { Infográfico Web }\end{array}$ & $\begin{array}{l}\text { Letramento no } \\
\text { Gênero }\end{array}$ & $\begin{array}{l}\text { Discussão do } \\
\text { tema "Operação } \\
\text { Lava Jato" por } \\
\text { meio de } \\
\text { diversos } \\
\text { gêneros }\end{array}$ & $\begin{array}{c}\text { Análise } \\
\text { contextual do } \\
\text { infográfico } \\
\text { "Operação } \\
\text { Lava Jato" }\end{array}$ & $\begin{array}{l}\text { Análise Discursiva } \\
\text { do infográfico } \\
\text { "Operação Lava } \\
\text { Jato" }\end{array}$ & $\begin{array}{l}\text { Análise Verbo - } \\
\text { Visual do } \\
\text { infográfico } \\
\text { "Operação Lava } \\
\text { Jato" }\end{array}$ & $\begin{array}{c}\text { Avaliação com } \\
\text { base na leitura de } \\
\text { Questões do ENEM } \\
\text { que empregam o } \\
\text { gênero infográfico }\end{array}$ \\
\hline Objetivo & $\begin{array}{c}\text { Verificar o } \\
\text { conhecimento } \\
\text { prévio dos alunos } \\
\text { com relação ao } \\
\text { gênero }\end{array}$ & $\begin{array}{c}\text { Reconhecer as } \\
\text { regularidades } \\
\text { do Gênero }\end{array}$ & $\begin{array}{c}\text { Constatar o } \\
\text { conhecimento } \\
\text { dos alunos } \\
\text { quanto ao tema } \\
\text { e ampliar seus } \\
\text { conhecimentos } \\
\text { por meio de } \\
\text { diversos } \\
\text { gêneros }\end{array}$ & $\begin{array}{l}\text { Realizar um } \\
\text { levantamento } \\
\text { do aspecto } \\
\text { contextual do } \\
\text { gênero } \\
\text { escolhido }\end{array}$ & $\begin{array}{c}\text { Identificar as } \\
\text { construções } \\
\text { discursivas } \\
\text { presentes no texto }\end{array}$ & $\begin{array}{c}\text { Averiguar a } \\
\text { correlação entre os } \\
\text { componentes } \\
\text { verbo-visuais } \\
\text { empregados no } \\
\text { infográfico }\end{array}$ & $\begin{array}{l}\text { Considerar os } \\
\text { conhecimentos } \\
\text { apreendidos por } \\
\text { meio de uma } \\
\text { atividade composta } \\
\text { por gêneros } \\
\text { infográficos } \\
\text { presentes em } \\
\text { provas do ENEM. }\end{array}$ \\
\hline
\end{tabular}

Recursos Materiais Data-show, quadro e giz, jornais e revistas, cópias de textos.
Duração
$2 h / a$
$2 \mathrm{~h} / \mathrm{a}$
$2 \mathrm{~h} / \mathrm{a}$
$2 \mathrm{~h} / \mathrm{a}$
$2 \mathrm{~h} / \mathrm{a}$
$3 \mathrm{~h} / \mathrm{a}$
1h/a 
Oficina 1: Gênero textual infográfico web

Nesta primeira oficina, pretende-se explicitar aos alunos de que maneira será conduzida a proposta de ensino e, posteriormente, identificar o que os alunos já sabem sobre o gênero infográfico focando, especialmente, o infográfico web que será estudado.

\section{Investigação: 0 que você já sabe}

a) Você já ouviu a palavra infográfico? Você se lembra em que contexto a ouviu?

b) Qual a primeira coisa que vem a sua mente ao ouvi-la?

c) Quem é o agente produtor dos infográficos?

d) Para quem são produzidos os infográficos?

e) Para quê?

f) Pense em alguma coisa que você gostaria de saber sobre os infográficos. Escreva a sua pergunta.

Espera-se que os alunos consigam responder às perguntas até o término das primeira e segunda oficinas, pois são as que irão se remeter especificamente às características do gênero, mas, caso ainda fiquem com dúvidas, é importante que o professor os oriente a pesquisar em outras fontes e tragam os resultados e/ou possíveis dúvidas.

Oficina 2: Letramento no gênero

Após constatar o conhecimento dos alunos com relação ao gênero e verificarmos suas dúvidas, na oficina 2, temos por intuito letrar o aluno no gênero infográfico; para tanto, serão levados em sala diversos infográficos para que os alunos possam verificar suas regularidades, analisando, principalmente, a estrutura composicional, temática e o estilo do gênero. 
Após a leitura dos textos, é preciso que o professor conduza os alunos a identificarem o que os textos têm em comum, fazendo algumas perguntas, como:

a) Os textos lidos discutem quais temáticas?

b) Como foram explorados, no texto, esses temas?

c) Você consegue identificar qual a estrutura composicional do gênero infográfico? Quais são suas características?

d) Você acredita que essas características são fixas em todos os infográficos?

e) O texto apresenta mais de um tipo de linguagem? Se sim, quais?

f) Você acredita que todos os infográficos apresentam o mesmo tipo de linguagem?

g) Você consegue identificar o motivo de se utilizar infográficos nestas reportagens?

h) Você achou que os infográficos ajudaram na compreensão da temática? Por quê?

i) Você já viu outros tipos de infográficos?

j) Sentiu dificuldades na compreensão deste gênero textual?

Oficina 3: Discussão do tema

Para verificar o conhecimento dos alunos quanto ao tema, o professor dará início levantando alguns questionamentos como: O que é corrupção? Como a corrupção atrapalha a vida da sociedade? Como ela pode ser combatida? Logo após as considerações, o professor pode distribuir imagens para exemplificar modelos de corrupção.

Ao discutir sobre suas impressões, far-se-á a leitura do gênero notícia de jornal "Caso Lava Jato - entenda o caso", retirado do site <http://lavajato.mpf.mp.br/entenda-o-caso>; concluída a leitura, a turma poderá ser dividida de acordo com os tópicos presentes na reportagem - As empreiteiras; Os Funcionários da Petrobrás; Operadores financeiros; Agentes políticos - cada grupo ficará responsável pela discussão de um tópico, 
apresentando-o à classe.

Antes da explicação, e para complementar a compreensão do texto, 0 professor mostrará um vídeo explicativo "Operação Lava Jato", de 6 min. e 48' disponível no site <http://especiais.g1.globo.com/videosinterativos/\#!/politica/operacao-lava-jato>, discutindo passo a passo sobre como se estruturou esta operação.

Oficina 4: Análise contextual

Nesta oficina, pretende-se que os alunos consigam identificar os aspectos contextuais do gênero infográfico web presente na reportagem do jornal Folha de S. Paulo Online, na qual discute a temática Operação Lava Jato. É importante frisar aos alunos que este jornal é um dos mais lidos no Brasil e tem grande tiragem e circulação, tanto no impresso quanto na edição online, principalmente, por ser o precursor neste novo formato.

Assim, por se tratar de um jornal online, as reportagens trazem as notícias de maneira rápida e com várias informações adicionais, ou seja, os textos possuem outras referências como base e tentam demonstrar imparcialidade, pois os textos publicados neste suporte apresentam na íntegra as informações contidas no impresso, porém é mais atualizado.

A parte das fotos e infográficos das edições originais em papel fazem parte da edição online, entretanto, a edição online traz o texto da Folha desde 1994, com um software de pesquisa instantânea, além de fóruns, enquetes e outros conteúdos midiáticos.

Os temas apresentados são de interesse geral e tem por intuito a busca de um jornal crítico, apartidário e pluralista, dados importantes para a compreensão dos alunos com relação aos infográficos que abordam a temática da corrupção. 
Oficina 5: Análise Discursiva do Infográfico

Nesta quinta oficina, será analisada a discursividade dos infográficos "Operação Lava Jato". Os alunos em duplas escolherão um infográfico da seção de infográficos do tema para redigirem um breve texto em que discorram sobre as características estruturais, temáticas e estilísticas, e como estes aspectos auxiliam na explicação; questões como: A linguagem é coloquial ou padrão? A proposta é esclarecida e detalhada de forma concisa, direta?. Quais tipos de linguagem são utilizados para a explicação do infográfico, linguagem visual, verbal? Essas perguntas servirão de base para nortear as análises dos alunos. Ao final deste exercício, cada dupla explanará sobre suas considerações.

Oficina 6: Análise verbo-visual

Na oficina 6, o professor deverá conduzir os alunos a uma análise dos aspectos verbo-visuais do infográfico. Essa análise levará à percepção de como a linguagem não verbal está indissociavelmente ligada à linguagem verbal para a construção do sentido do texto. Além disso, nessa oficina, será possível mostrar aos alunos como o texto traz em si valores ideológicos imbricados, e como a compreensão desses valores só é possível se a leitura integrar todos os elementos do texto.

\section{Atividade 1}

Primeiramente, o professor apresentará as imagens a seguir e perguntará aos alunos o que as diferencia, levando-os a perceber o que o traje pressupõe, que não se trata de alguém comum, mas de um sujeito específico, no caso, um político. Dessa forma, os alunos serão capazes de concluir que uma imagem também é uma construção social, ou seja, sofre influência de uma visão de mundo e, portanto, não é neutra de sentido e é por isso que a leitura de um texto deve ser realizada em todos os seus pormenores. 
Figura 14: Ideograma utilizado no infográfico

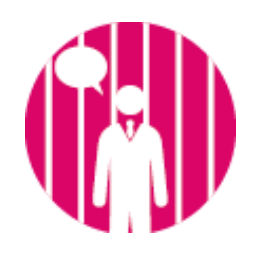

O mesmo pode ser realizado com os outros infográficos do texto. 0 professor pode dar autonomia para os alunos buscarem outras construções de sentido no texto, considerando as contribuições dos alunos e mediando a compreensão. Nessa etapa, os alunos perceberão, também, que a compreensão do texto se dá por meio da integração das duas linguagens, num processo de ancoragem entre verbal e visual, daí a utilização do termo verbo-visual para esta oficina, uma vez que não se trata de dois processos distintos de leitura - a da imagem e do texto escrito - mas de um processo único que considera as múltiplas linguagens para a compreensão do sentido global.

\section{Atividade 2}

Nesta segunda etapa da oficina, o professor irá mostrar aos alunos a figura da "liga da justiça", a imagem pode ser projetada, entregue aos alunos ou colada no quadro. A atividade pode ser iniciada questionando os alunos sobre seus conhecimentos acerca dos personagens dessa figura: quem são, 0 que fazem, o que sabem sobre eles, como estão dispostos na imagem etc. Depois o professor pedirá aos alunos que digam em que medida essa figura se relaciona com o infográfico. É esperado que os alunos, através do reconhecimento da disposição dos super-heróis na imagem, a correlacionem com a foto dos procuradores responsáveis pela investigação, mas caso isso não aconteça, o professor deverá apontar as semelhanças e mostrar aos alunos a significação da disposição em "V".

Por último, o professor deve levar os alunos a compreenderem como essa disposição na foto é proposital e constituinte de sentido e que a compreensão dessa construção só é possível por meio de inferências, pela busca de informações extratextuais. Esse é um bom momento para destacar a 
importância de várias leituras de textos com diferentes linguagens, pois muitos textos mantêm relação intertextual com outros, e esse recurso é altamente explorado pelos concursos nacionais, inclusive o ENEM.

\section{Oficina 7: Avaliação}

A oficina 7 encerrará nossa proposta de ensino; será aplicado aos alunos um simulado do ENEM com questões sobre a "Operação Lava Jato". Após todo o estudo sobre o assunto com os infográficos, o professor verificará a compreensão leitora dos alunos quanto aos infográficos, e os alunos poderão testar seus conhecimentos averiguando se realmente aprenderam sobre 0 tema.

\section{Conclusão}

Esse trabalho teve como foco central propor um plano de ensino do gênero infográfico $w e b$, a fim de auxiliar o trabalho docente no que se refere ao trabalho com os gêneros textuais em sala de aula, principalmente, focando a importância da leitura global do texto, incluindo, portanto, os textos multimodais.

Assim, escolhemos para a análise uma reportagem da Folha de S. Paulo Online que tratava do tema Operação Lava Jato, assunto atual em nossa sociedade, em que há o emprego de diversos recursos semióticos, focando, nesta pesquisa, o infográfico web.

Desta maneira, trouxemos os estudos de Coscarelli (1999) e Paiva (2011) para a base de análise e as contribuições sobre sistema semiótico de Nascimento (2011). As análises foram com base nos aspectos contextuais, discursivos e verbo-visuais, a fim de explorarmos de maneira eficiente o gênero escolhido.

Após a análise, com o intuito de auxiliar ainda mais no trabalho docente, com gêneros digitais multimodais, elaboramos um plano de ensino composto por 3 semanas de aulas, destinado aos alunos de Ensino Médio, por 
reconhecermos a importância da leitura e compreensão dos diversos gêneros e o peso que o Exames Nacionais do Ensino Médio tem nesta fase, afinal, por meio da prova do ENEM, o estudante pode conseguir vagas em instituições de ensino superior tanto públicas quanto privadas.

Em vista disto, acreditamos que é necessária a inserção dos gêneros digitais no ensino de língua, visto que eles circulam em nossa sociedade e têm feito parte da vida da maioria dos alunos, pois é sabido que os alunos acessam a internet diariamente. Assim, por reconhecerem os gêneros e os encontrarem em seu cotidiano, o interesse por parte do alunado será maior, e nosso objetivo é letrá-los nos mais variados textos que circulam na sociedade.

\section{Referências}

BAKHTIN, Mikhail; VOLOCHÍNOV, Valentin Nikolaevich. A interação verbal. In: BAKHTIN, M.; VOLOCHÍNOV, V. N. Marxismo e filosofia da linguagem. São Paulo: Hucitec, 1995. p. 110-127.

BRONCKART, Jean Paul. As condições de produção dos textos. In: Atividade de linguagem, textos e discursos: por um interacionismo sócio-discursivo. Trad. Anna Rachel Machado, Péricles Cunha. São Paulo: EDUC, 2003.

BRONCKART, Jean Paul. Os tipos de discurso. In: Atividade de linguagem, discurso e desenvolvimento humano. Campinas: Mercado de Letras, 2006.

DIONISIO, Ângela Paiva. Gêneros textuais e multimodalidade. In.: KARWOSKI, Acir Mário; GAYDECZKA; BRITO, Karin Slebeneicher (Orgs.). Gêneros textuais: reflexões e ensino. São Paulo: Parábola Editorial, 2011. pp. 137-152.

G1.Operação Lava Jato. Disponível em <http://especiais.g1.globo.com/videosinterativos/\#!/politica/operacao-lava-jato>. Acesso em: 22 out. 2015

KATO, Mary. O aprendizado da leitura. 4 ed. São Paulo: Martins Fontes, 1995.

KRESS, Gunther; LEEUWEN, Theo Van. Multimodal discourse: The modes and media of contemporary communication. London: Bloomsbury Academic, 2010.

MARCUSCHI, Luiz Antônio. Gêneros textuais emergentes no contexto da tecnologia digital. In: MARCUSCHI, Luiz Antônio; XAVIER, Antônio Carlos (Orgs.). Hipertexto e gêneros digitais: novas formas de construção de sentido. 2 ed. Rio de Janeiro: Lucerna, 2005. p. 13-31. 
MARCUSCHI, Luiz Antônio. Gêneros textuais: dinamicidade, configuração, circulação. In.: KARWOSKI, A. M. GAYDECZKA, Beatriz, BRITO, Karim Siebeneicher. Gêneros textuais: reflexões e ensino. União da Vitória - PR, 2005.

MARCUSCHI, Luiz Antônio. Produção Textual, análise de gêneros e compreensão. São Paulo: Parábola Editorial, 2008.

MPF combate a corrupção. Entenda o caso - Caso Lava Jato. Disponível em<http://lavajato.mpf.mp.br/entenda-o-caso>. Acesso em: 22 out. 2015.

NASCIMENTO, Roseli Gonçalves do; BEZERRA, Fábio Alexandre Silva; HEBERLE, Viviane Maria. Multiletramentos: iniciação à análise de imagens. Linguagem \& Ensino, Pelotas, v. 14, n.2, p. 529-552, jul./dez. 2011.

OLIVEIRA, Derli Machado. Gêneros multimodais e multiletramentos: novas práticas de leitura na sala de aula. In: Anais... VI Fórum Identidades e alteridades II Congresso Nacional Educação e Diversidade -2013, UFS Itabaiana/SE, Brasil.

PAIVA, F. A. O gênero textual infográfico: leitura de um gênero textual multimodal por alunos da $1^{\text {a }}$ série do ensino médio. Revista L@el em (Dis)curso. v. 3, 2011, p. 87-101.

PAIVA, Francis Arthuso. A Leitura de Infográficos da Revista Superinteressante: procedimentos de leitura e compreensão. 2009. 204 f. Dissertação (Mestrado em Estudos Linguísticos) - Universidade Federal de Minas Gerais, Belo Horizonte, 2009.

PINHEIRO, Petrilson Alan. Gêneros (digitais) em foco: por uma discussão sóciohistórica. Alfa: Revista de Linguística 54.1 (2010): 33+. Academic OneFile. Web. 10 set. 2015. p.33-58.

ROJO, Roxane; MOURA, Eduardo. Multiletramentos na escola.São Paulo: Parábola Editorial, 2012.

SHEPHERD, Michael; WATTERS, Carolyn. The Functionality Attribute of Cybergenres. Proceedings of the 32nd Hawaii International Conference on System Sciences - 1999.

SOLÉ, Isabel. Estratégias de Leitura. 6 ed. Porto Alegre: Artmed, 1998. 